\title{
Rigid Confocal Endoscopy of the Larynx
}

\author{
Tino Just ${ }^{1}$, Joachim Stave ${ }^{2}$, Oliver Stachs², Gabriele Witt ${ }^{3}$, \\ Rudolf Guthoff ${ }^{2}$ and Hans Wilhelm Pau ${ }^{1}$ \\ ${ }^{1}$ Department of Otorhinolaryngology, Head and Neck Surgery, University of Rostock \\ ${ }^{2}$ Department of Ophthalmology, University of Rostock \\ ${ }^{3}$ Department of Phoniatry and Pedaudiology, University of Rostock
}

Germany

\section{Introduction}

Early detection of pre-malignant and malignant lesions of the larynx may be the best method to improve patient quality of life and survival rates. Microlaryngoscopy, the Kleinsasser method (Kleinsasser, 1962), was introduced in 1962 as a new procedure to diagnose laryngeal diseases. Diagnosis of laryngeal disease depends on both the extent of sampling and the method used (McGuirtBrowne, 1991). To improve the accuracy of sampling during microlaryngeal surgery (MLS) and to maximize survival for patients with cancer of the larynx, the search for new in-vivo technologies is of great clinical relevance. The risk of local recurrence increases from $32 \%$ to $80 \%$ when positive margins are found (Batsakis, 1999). Several techniques have been introduced in laryngology to detect early stages of laryngeal cancer. Stroboscopy was thought to detect early laryngeal cancer, but when applied preoperatively, this method fails to differentiate clearly between invasive carcinoma of the true vocal cord and intracellular atypia and to determine the penetration depth of the laryngeal cancer (Colden et al., 2001). Several methods were introduced to improve the accuracy of sampling during microlaryngoscopy. Among these technologies, "optical" biopsy (Kothe et al., 2005), rigid endoscopy (Kawaida et al., 1998), contact endoscopy (Andrea et al., 1995a; Andrea et al., 1995b; Arens et al., 2003; Carriero et al., 2000; Cikojevic et al., 2008; Wardrop et al., 2000), autofluorescence endoscopy (Delank et al., 2000; Gillenwater et al., 1998; Harries et al., 1995; Malzahn et al., 2002), aminolevulinic acidinduced fluorescence (Arens et al., 2007; Csanady et al., 2004; Gillenwater et al., 1998) and optical coherence tomography (OCT) (Armstrong et al., 2006; Lüerßen et al., 2006; Wong et al., 2005) should be noted. Except for the latter method, all technologies mentioned mainly visualize macroscopically suspect lesions of the larynx. OCT is an optical imaging technique that clearly identifies basement membrane violation from laryngeal cancer, but fails to penetrate bulky exophytic tumors (Armstrong et al., 2006). Laryngeal tumors mostly appear as keratotic lesions. So far, there is no information on the correlation between penetration depth and thickness of keratotic lesions using OCT. Additionally, OCT fails to visualize nuclear abnormalities that will be important to differentiate between hyperplasia of the epithelium and dysplasia or early cancer (Armstrong et al., 2006). OCT images can be obtained at depths of up to $2 \mathrm{~mm}$ (Brezinski et al., 1996) and provide approximately 3-35 $\mu \mathrm{m}$ lateral and 15-30 $\mu \mathrm{m}$ axial resolution when applied to epithelial tissue (Schmitt, 1999). 
OCT provides test outcomes for differentiation between benign laryngeal lesions and dysplasia/carcinoma in situ with sensitivity of $88 \%$, specificity of $89 \%$, and predictive accuracy of $88 \%$ (Just et al., 2010).

In contrast to OCT, laser scanning microscopy (LSM) provides cellular and sub-cellular information and achieves a resolution of $1 \mu \mathrm{m}$ (Rajadhyaksha et al., 1995). The basic principle of LSM is that light from a laser passes through the illumination aperture, is reflected by a dichroic mirror, and is finally focused on one point in the specimen (Stave et al., 2002). Laser light that is backscattered from the specimen is captured through an aperture. Only the light from the in-focus plane is imaged. Out-of-focus light is eliminated. This gives a high-resolution image of cellular structures at the focal point. To obtain a twodimensional image, the confocal microscope scans across the tissue at a single depth, recording images from a number of adjacent focal points. By moving the focal plane, different layers of the tissue are displayed. The imaging depth is up to $0.5 \mathrm{~mm}$ and allows identification of many intra-epithelial lesions (Collier et al., 2002; Rajadhyaksha et al., 1995; White et al., 1999). With special software, it is possible to 3D-reconstruct the volume scans in vivo. This procedure has been termed "virtual biopsy" (Amos \& White, 2003; Kiesslich et al., 2004). The illumination of the tissue (penetration depth of the laser) depends primarily on the keratinization of the epithelium. It was hypothesized that increased levels of keratin diminish the ability for illumination of the deeper cell layer of the epithelium. The reason for this is the higher refractive index of keratin compared to cytoplasm (Brunsting \& Mullaney, 1974). However, the penetration depth of LSM is limited due to two factors: background due to out-of-focus scattering and signal-to-noise ratio (Schmitt et al., 1997).

Recently, a confocal microscope has been miniaturized and integrated into a conventional flexible endoscope (Venkatesh et al., 2009). The diameter of the distal tip of the endoscope is $12.8 \mathrm{~mm}$ including the integrated miniaturized confocal microscope with a diameter of 5 $\mathrm{mm}$ (Venkatesh et al., 2009). The use of endoscopes with this large diameter has so far been limited to the gastrointestinal tract. This newly developed imaging system provides in-vivo histology during ongoing endoscopy and can be used to diagnose different diseases of the gastrointestinal tract (Kiesslich et al., 2005; Kiesslich et al., 2006; Kiesslich \& Neurath, 2005; Kiesslich \& Neurath, 2006; Venkatesh et al., 2009). There have been initial attempts to use the mentioned imaging technology for in-vivo assessment of the oropharyngeal mucosa. After topical application of acriflavine and intravenous fluorescein, cellular and sub-cellular structures of the anterior human oropharyngeal region were displayed (Haxel et al., 2010). Using a confocal microscope for use in ophthalmology, we obtained cellular and subcellular information in vivo without any staining (Just et al., 2006a; Just et al., 2007a; Just et al., 2005). Figure 1 demonstrates an in-vivo image of healthy human cheek mucosa.

Next, we commenced ex-vivo studies of laryngeal mucosa (Figures 2-7). A pre-clinical trial has been carried out to assess benign, pre-malignant and malignant lesions of the human larynx (Just et al., 2006b; Just et al., 2007b). Quantitative analysis of cellular and morphological features, e.g. nuclear size, nuclear density, number of nuclei per cell, nucleus/cytoplasm ratio, regularity of the cell layers, morphology of cells in a cell layer, and occurrence of cellular junctions, showed good agreement with histology, suggesting that LSM can identify pathologies in vivo (Just et al., 2006b). Confocal microscopy of the healthy human larynx revealed that the border between the superficial and basement cell layer is clearly visible, while the basement membrane itself cannot be detected (Fig. 2). In contrast to carcinoma (Fig. 3), dysplasia is diagnosed when the cellular junctions remain intact (Fig. 6). Figures 4 and 5 depict the typical findings of a papilloma (two papillae are indicated) and 


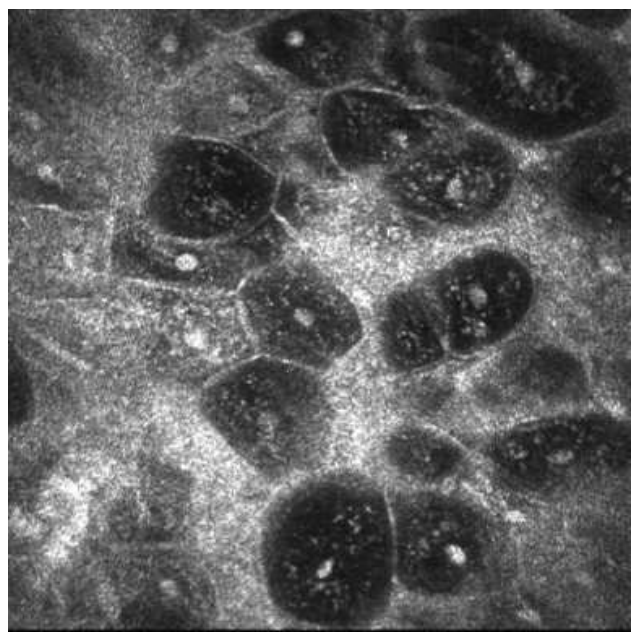

Fig. 1. Normal cheek mucosa. LSM displays a homogeneous cell architecture.

inflammation (koilocyte is marked). Visualization of the basement membrane is a precondition for in-vivo diagnosis of precancerous lesions. Figure 7 shows the infiltration of a carcinoma into the subepithelial space. Figures 2-7, obtained ex vivo, illustrate the hallmark differences between normal epithelium of the larynx and the epithelium of benign and pre-cancerous and cancerous lesions. The information from our ex-vivo studies of the human larynx is limited; we regard them as a necessary prelude to applying this technology in vivo during microlaryngoscopy.

To accomplish this, a rigid endoscope has been developed emerging as a potential tool for detecting pre-malignant lesions in vivo without the need for explorative excision. The

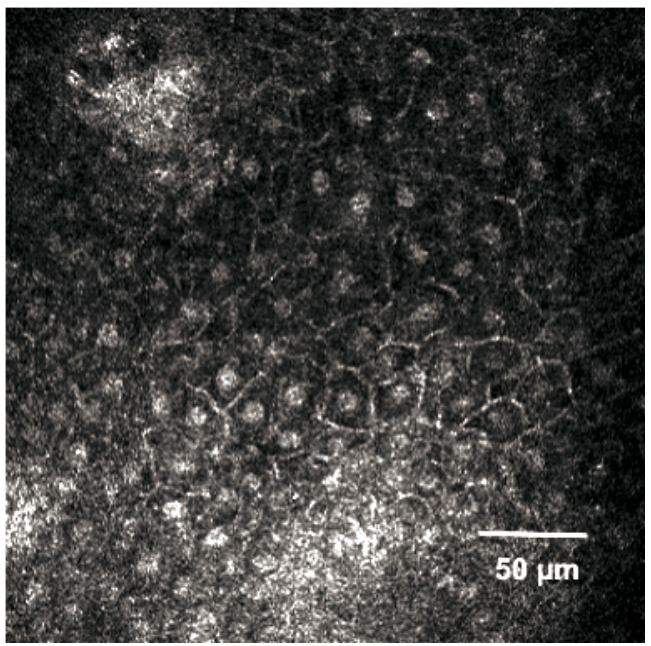

Fig. 2. Ex-vivo LSM image of healthy human true vocal cord epithelium at a depth of $5 \mu \mathrm{m}$. Regular cell architecture is apparent and both nuclei and cell membrane are clearly visible. 


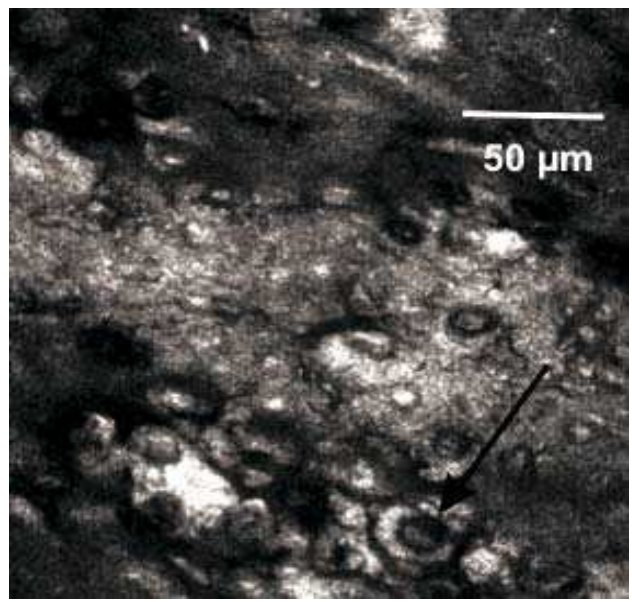

Fig. 3. Carcinoma. Ex-vivo LSM image presents all criteria of malignancy: enlarged nuclei of enlarged cells with variable shapes, clusters of cells, increased nucleus/cytoplasm ratio, irregular cell architecture and loss of cellular junctions.

experiments focus on the in-vivo application of LSM as a technology that enables visualization of cellular and sub-cellular information from the larynx epithelium. In our opinion, this technology has a high potential to significantly improve the detection rate, prevention and therapy of laryngeal cancer and its precursors. The application of this method intraoperatively is of scientific and clinical importance.

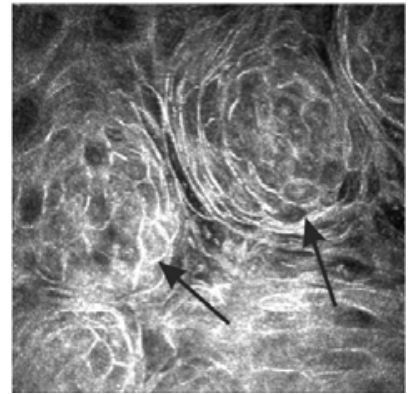

Fig. 4 Ex-vivo image of papilloma (arrows)

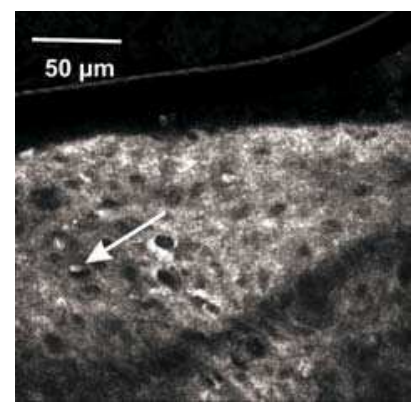

Fig. 5. Ex-vivo image of inflammation (koilocyte marked)

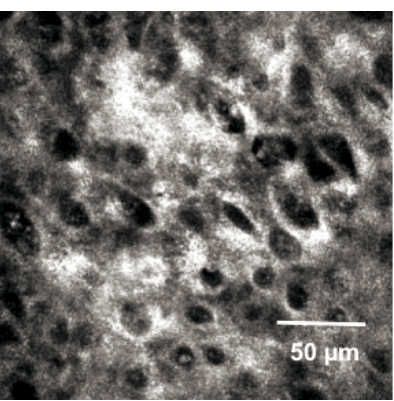

Fig. 6. Ex-vivo image of dysplastic cells

Next, we describe our approach to use confocal microscopy during microlaryngoscopy. Requirement was to construct rigid endoscopes rather than flexible probes. The potentially high impact of RCE is due to several unique properties and recent technical developments:

1. Imaging depths of $0.2-0.5 \mathrm{~mm}$ allow reliable identification of many intra-epithelial lesions (Collier et al., 2002; Rajadhyaksha et al., 1995; White et al., 1999).

2. LSM provides longitudinal-sections of the tissue and allows for characterization of normal laryngeal epithelium and of laryngeal lesions from different histogenetic origins (Just et al., 2006b; Just et al., 2007b). 
3. Application of LSM gives the opportunity for rapid acquisition of high-quality images of the laryngeal tissue (Stave et al., 2002).

4. Good correlation between LSM images and conventional histology were achieved in normal tissue, but also in benign and cancerous lesions of the larynx (Just et al., 2006b; Just et al., 2007b) and oropharynx (Just et al., 2008; White et al., 1999).

5. Rigid endoscopes seem to be easier to handle during microlaryngoscopy than flexible endoscopic systems.

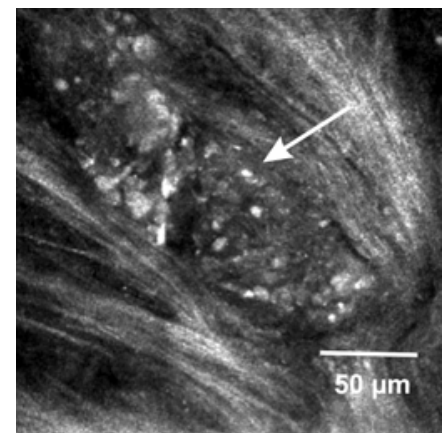

Fig. 7. Ex-vivo LSM image of infiltration of carcinoma into the subepithelial space (arrow)

\section{Imaging system, analysis and application}

A modified Heidelberg Retina Tomograph II (HRTII) (Heidelberg Engineering GmbH, Heidelberg, Germany) is used. The rigid endoscope is connected onto the scanner. Polarized light travels through a $\lambda / 4$ plate. Reflections may occur at the water immersion objective and the endoscope. Illumination is delivered by a $670-\mathrm{nm}$ diode laser. For endoscopic use, the $\lambda / 4$ plate of the HRTII is removed to avoid strong reflections. This leads to a percentage reduction in the image quality. In order to improve the image quality, the laser power of the HRTII scanner was increased for animal experiments and for the first clinical applications.

Three different modes can be used for data sampling. In the volume mode or 3D imaging mode, 40 image planes are stored. The distance between two subsequent image planes is about $2 \mu \mathrm{m}$. Thus, the depth range is $80 \mu \mathrm{m}$ per scan. Through resetting of the start plane, up to 4 volume scans can be made. The maximal penetration depth is about $300 \mu \mathrm{m}$ and ranges from 100 to $450 \mu \mathrm{m}$. The acquisition time for a volume scan is about $6 \mathrm{~s}$. In sequence acquisition mode, up to 100 images are stored. In section mode, single images can be stored.

\subsection{Design of the rigid endoscope and the adapter}

The prototype of the custom-made endoscope (length: $23 \mathrm{~cm}$, diameter: $5 \mathrm{~mm}$ ) consists of a steel endoscope shaft with integrated rod lenses and one microscope objective at the endside of the endoscope (diameter $3.5 \mathrm{~mm}$ ). Two different endoscopes have been developed. One endoscope has a flat microscope objective at the end of the endoscope. A second endoscope has a central hole perforation plate at the end-side of the endoscope. This modification avoids tissue compression in the field of vision. A flexible, transparent solid piece of cement is used to connect two adjacent rod lenses. This flexible material reduces the risk of damage to the rod lenses. The cement is non-scattering and does not impair the light 
transfer and image quality. The numerical aperture of the system is 0.9 and is limited by the endoscope. The endoscope is autoclavable and CE-certified. A connector has been developed (KARL STORZ GmbH \& Co. KG; Tuttlingen, Germany) to connect the HRTII to the rigid endoscope (Fig. 8). With the connector, the starting plane can be set manually. To achieve optical sectioning of the tissue, the scanning mechanism of the HRTII needs to be activated. The devices (HRTII, adapter, and endoscope) supply images of $400 \times 400 \mu \mathrm{m}$ and reach average penetration depths of $100-300 \mu \mathrm{m}(\lambda / 4$ plate of the HRTII was removed). The lateral and axial resolutions are about $1-2 \mu \mathrm{m}$ and $2 \mu \mathrm{m}$, respectively.

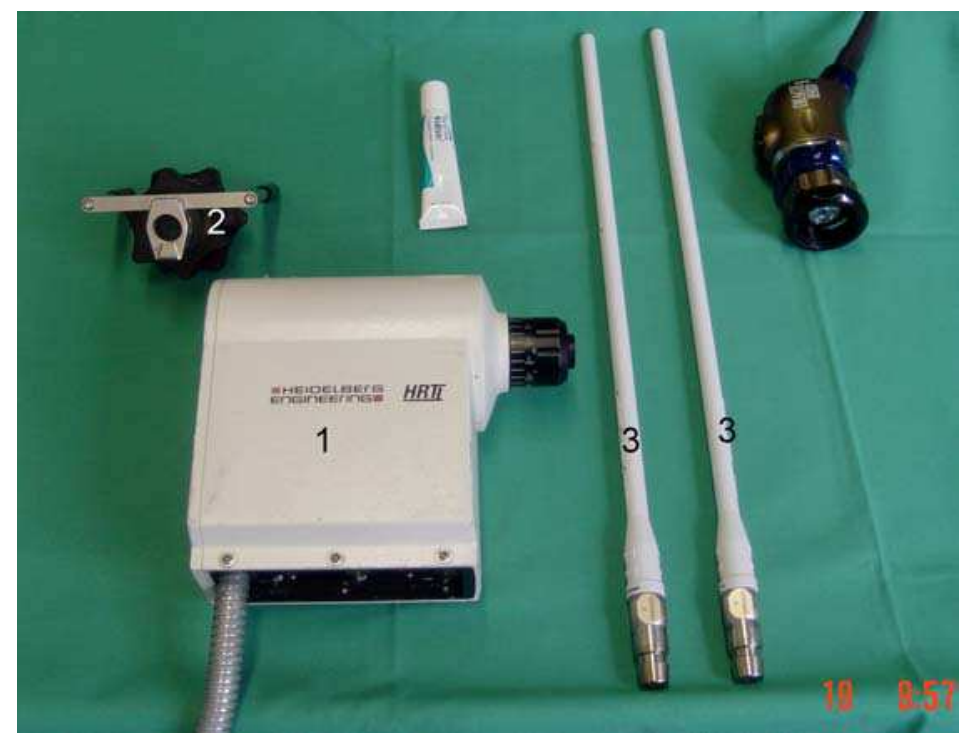

Fig. 8. Devices for in-vivo assessment of laryngeal mucosa.

1 - Scanner of the HRTII.

2 - Adapter to connect the endoscope to the scanner.

3 - Rigid endoscopes.

\subsection{Image analysis and classification of squamous intra-epithelial lesions (SILs)}

Confocal microscopic images are captured and stored in a data bank together with the microscopic images obtained during microlaryngology. The corresponding histopathological slices are reviewed separately. Each case is graded on a two-tiered scale as mild/moderate dysplasia (resembling low-grade squamous intra-epithelial lesion (SIL)), or severe dysplasia/carcinoma in situ (resembling high-grade SIL). Representative cases are discussed and arranged together with clinical and histological images in an image gallery of ascending severity SILs for synoptic viewing of lesions, thus enhancing reproducibility.

\subsection{Intraoperative application}

The larynx is exposed during microlaryngoscopy using laryngoscopes (Fig. 9). Suspicious lesions are identified with the operating microscope or with conventional endoscopes $\left(0^{\circ}\right.$, $\left.30^{\circ}, 70^{\circ}\right)$. 
For confocal endoscopy, the RCE is inserted through the laryngoscope (Fig. 10). The tip of the endoscope is gently placed on the lesion under macroscopic or endoscopic control. To avoid strong reflections, a contact gel (Vidisic ${ }^{\circledR}$, Dr Mann Pharma, Berlin, Germany) is used. The key step in this procedure is to take a biopsy as precisely as possible from the same laryngeal region as for confocal endoscopy. This procedure enables us to compare the confocal-microscopic findings with histology at a later stage.

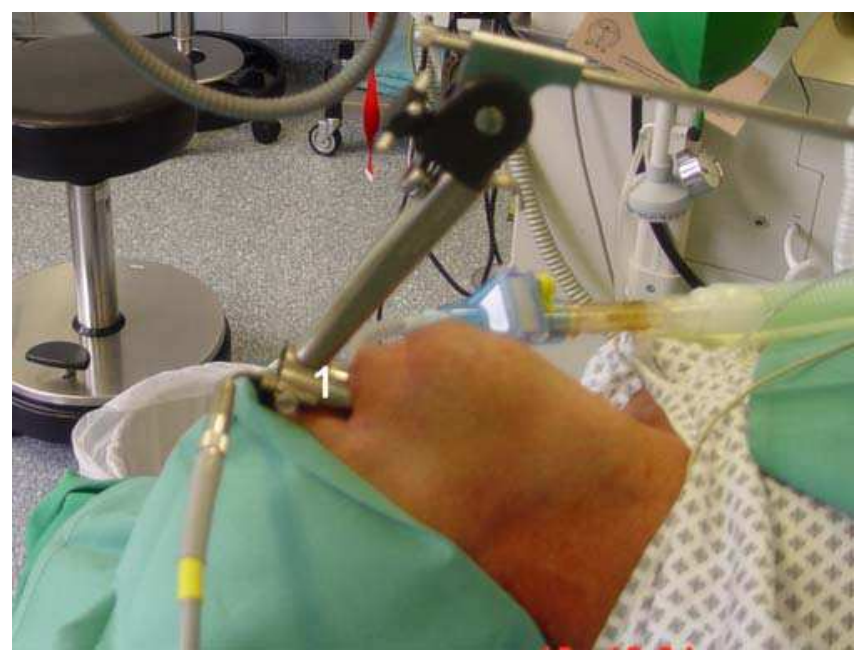

Fig. 9. Clinical setting during microlaryngoscopy.

1 - Laryngoscope was inserted into the oral cavity.

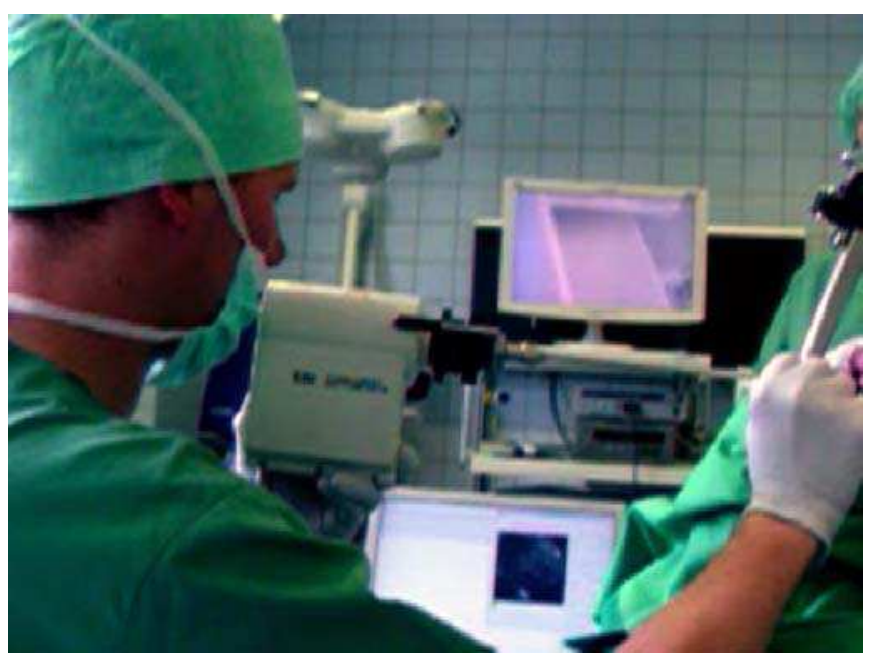

Fig. 10. Clinical setting. Rigid confocal endoscope needs to be inserted through the laryngoscope either under endoscopic or macroscopic control. 


\section{Human larynx findings with in-vivo-RCM}

Figure 11 shows images of a volume scan through the epithelium of a healthy true vocal cord. Epithelial cell layers are visible up to a depth of $80 \mu \mathrm{m}$ (first series). The second volume scan of the same vocal cord demonstrates the subepithelial fibers underneath the epithelium (Fig. 12).
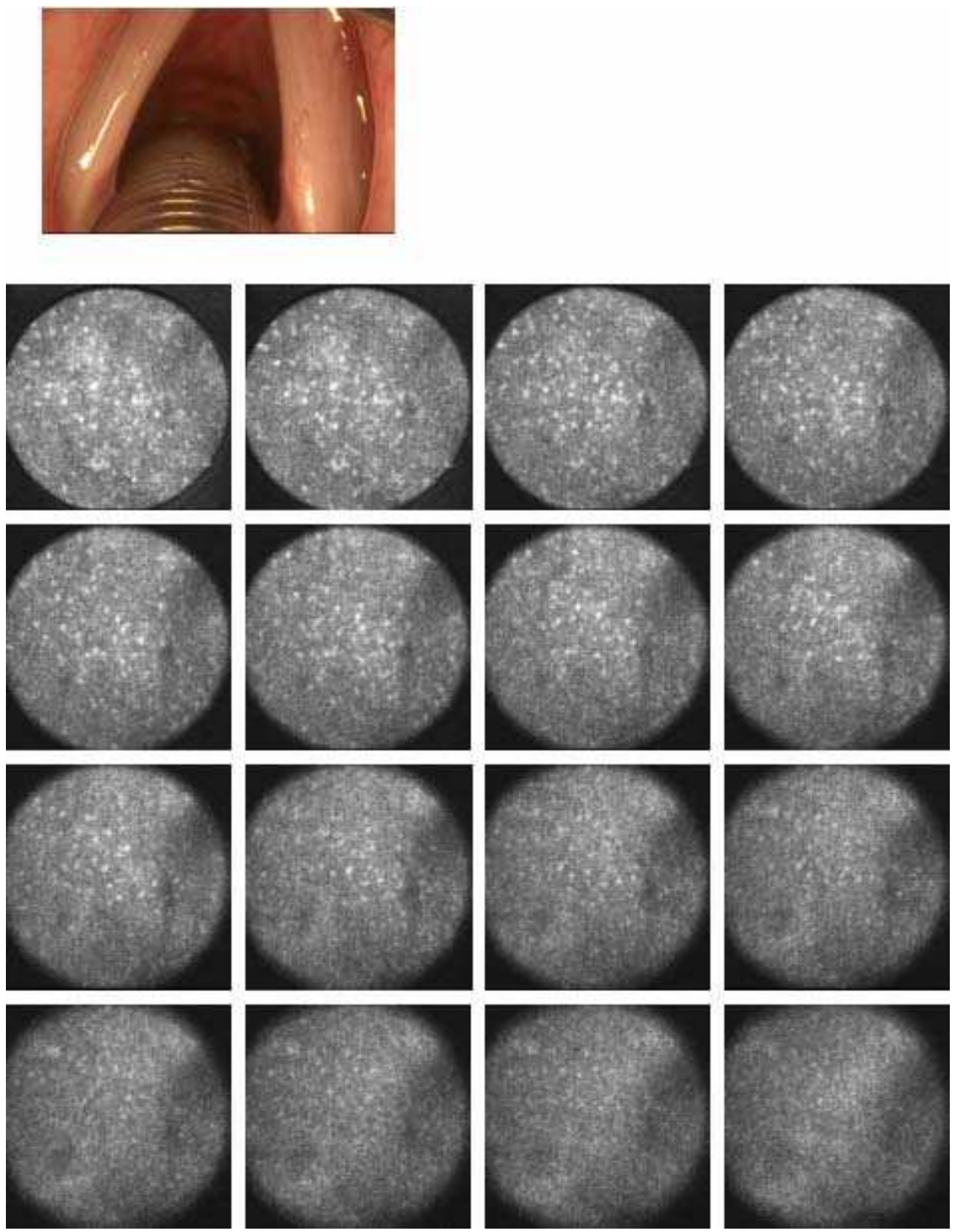

Fig. 11. Volume scan through a healthy true vocal cord. Cellular structures are visible up to $80 \mu \mathrm{m}$ (stepwise volume scan started from the surface of the epithelium). 

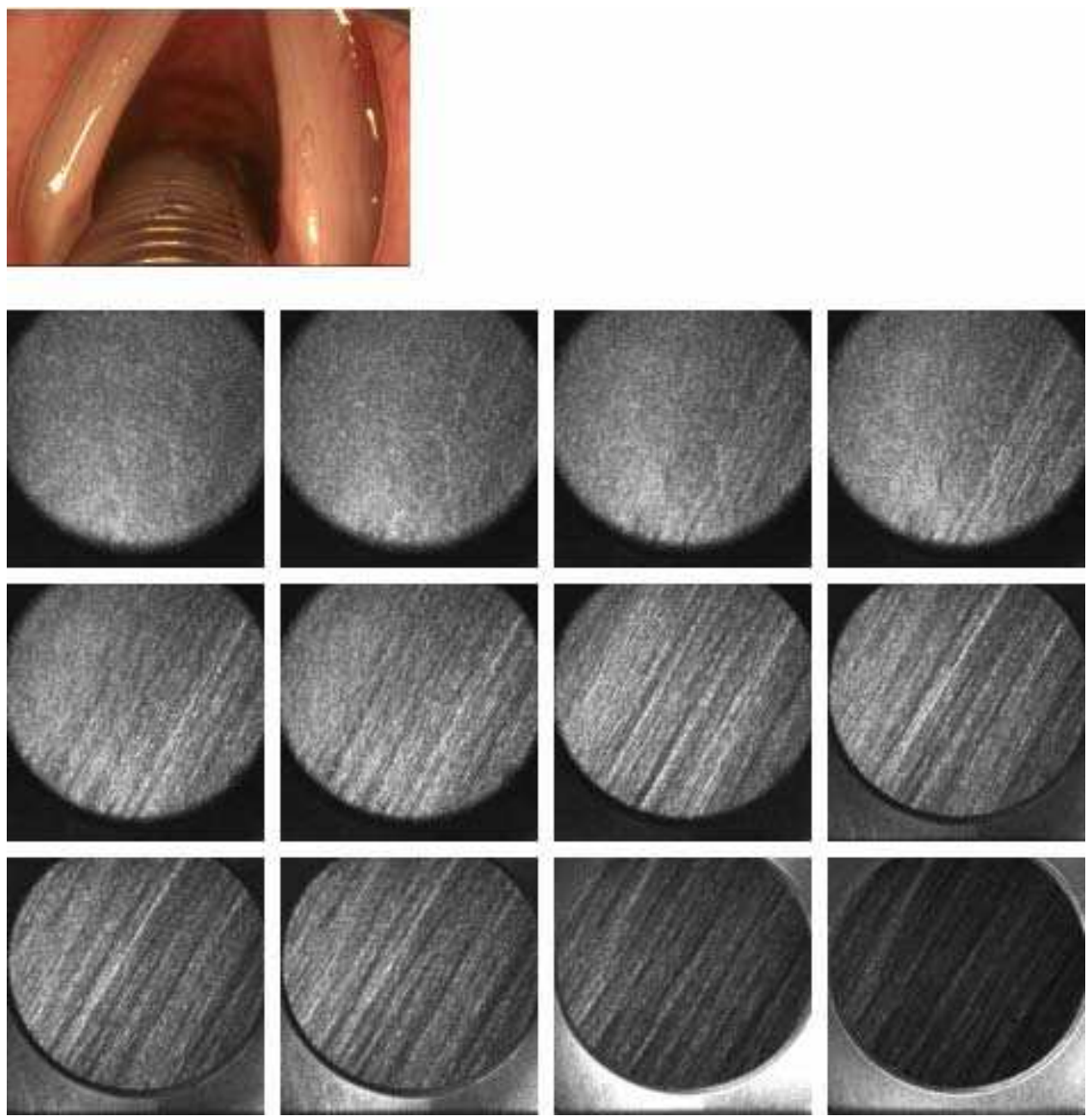

Fig. 12. Volume scan through a healthy true vocal cord. Subepithelial fibers are visible (stepwise volume scan started from basal cell layer). 

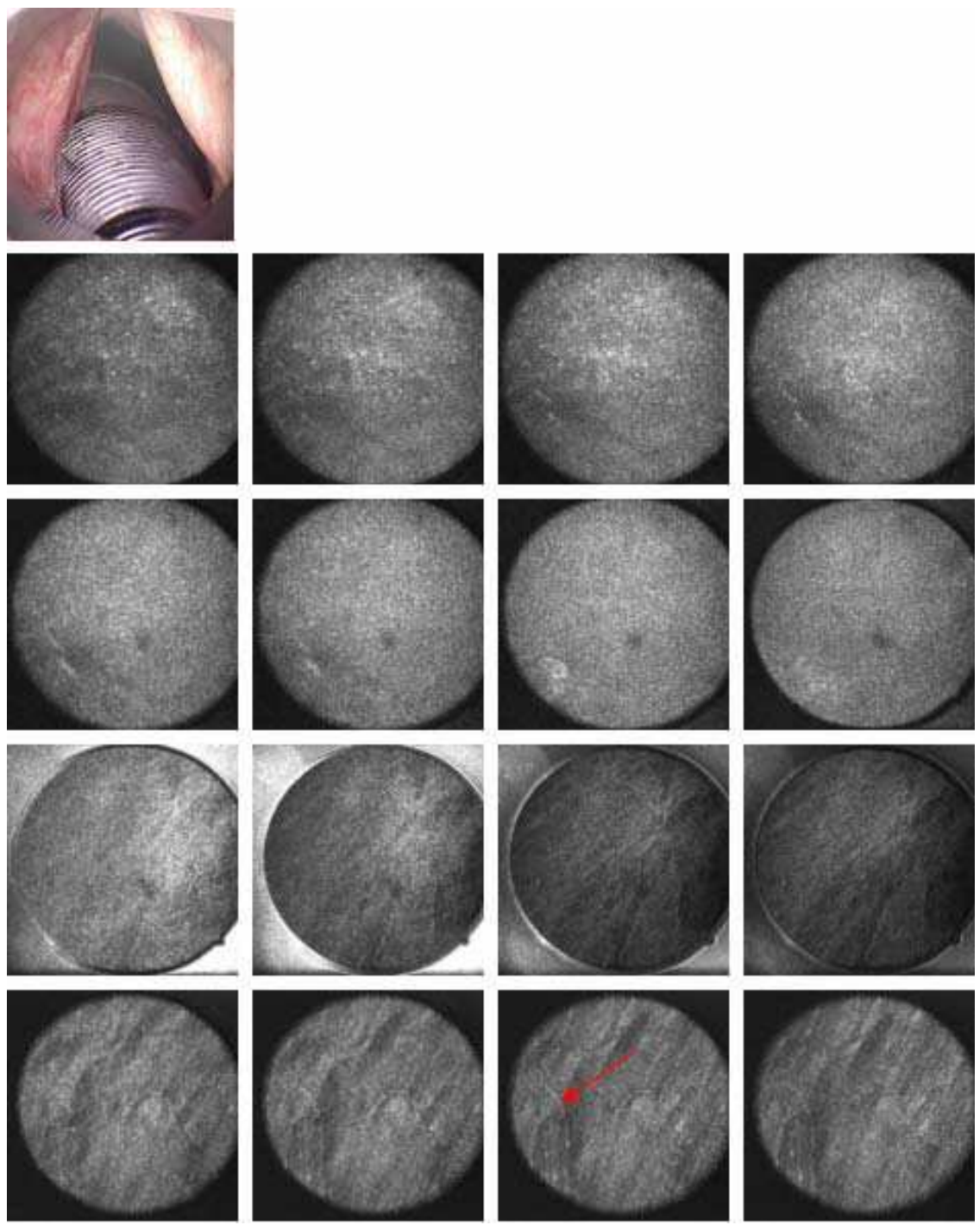

Fig. 13. Three months after left-sided cordectomy due to T1 laryngeal cancer. The images through the epithelium display no dysplastic cells. Vessel loops are visible in the subepithelial space. Histology revealed inflammation, but no dysplasia. 

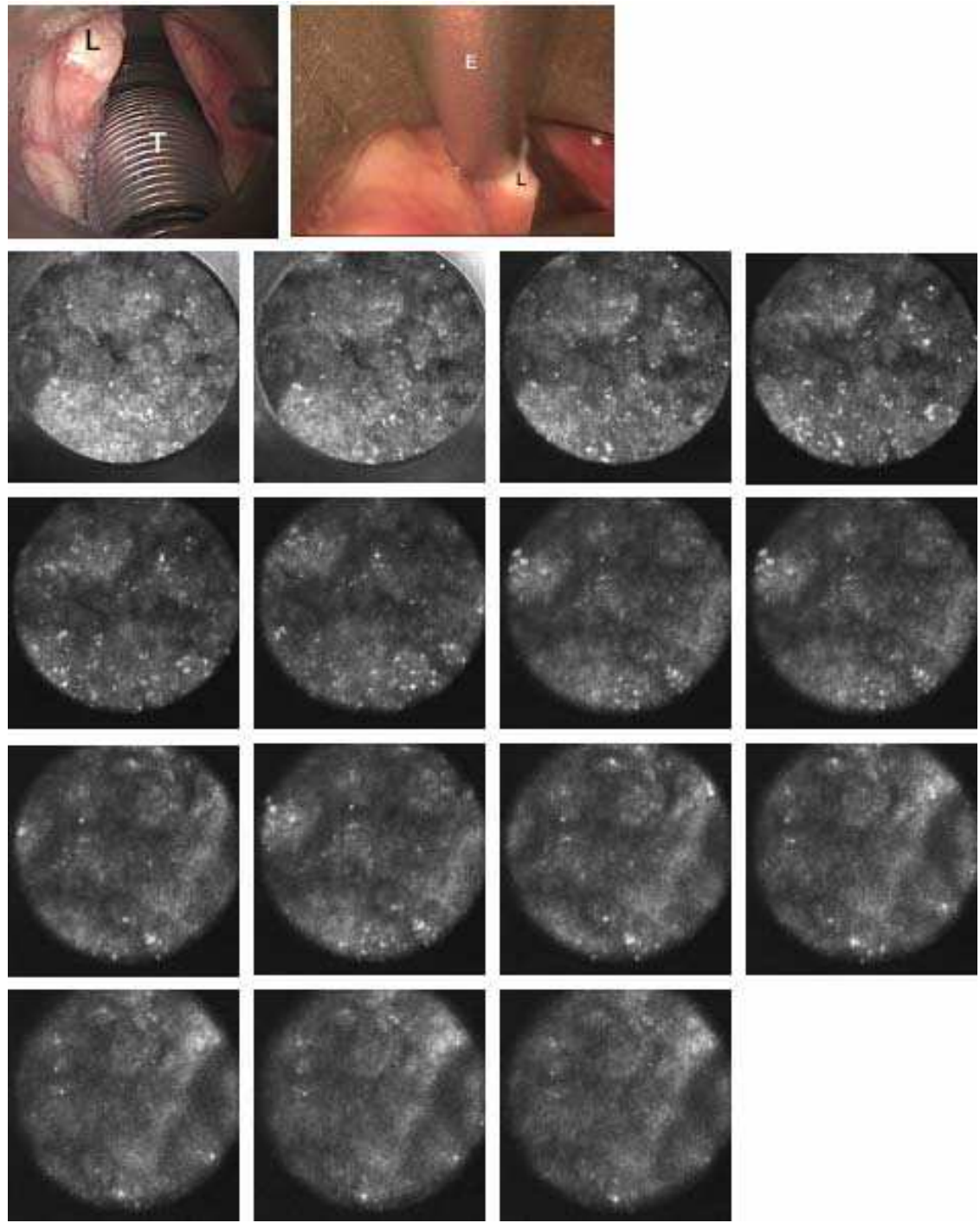

Fig. 14. Keratotic lesion of the left true vocal cord. LSM detected epithelial changes (irregular cell architecture and dysplastic cells). Histology revealed microinvasive carcinoma. L, lesion; $\mathrm{T}$, tube; $\mathrm{E}$, rigid confocal endoscope. 
RCE findings are shown for a 56-year-old man 3 months after $\mathrm{CO}_{2}$-laser assisted left-sided cordectomy (Fig. 13). The thin epithelial layer appears homogeneous and regular. No cellular abnormalities could be detected with confocal microscopy. Histology reveals inflammation but no dysplasia. Vessel loops are visible underneath the epithelium (arrow).

Figure 14 demonstrates a keratotic lesion of the posterior third of the left true vocal cord of a 59-year-old man who had undergone laser surgery of both sides several years earlier. Epithelial changes can be detected with confocal microscopy. Representative RCE images of a volume scan demonstrate enlarged nuclei of enlarged cells with variable shapes, clusters of cells, increased nucleus/cytoplasm ratio, and irregular cell architecture (Fig. 15). These are criteria for dysplasia. Histology revealed severe dysplasia.

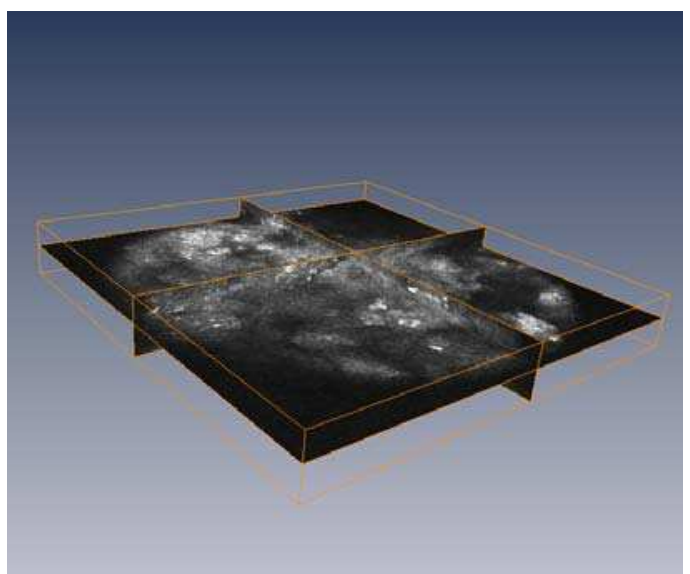

Fig. 15. 3D reconstruction of a volume scan (image size $400 \times 400 \times 80 \mu \mathrm{m})$ (carcinoma, compare with Fig. 14).

\section{Future research and developments}

To detect early laryngeal cancer, a precise biopsy is of great importance. Confocal microscopy has great potential for early diagnosis in laryngeal cancer. Initially, confocal microscopy was applied outside the larynx in ex-vivo studies (Just et al., 2006b; Just et al., $2007 \mathrm{~b}$ ) and later in vivo for detection of intraoral lesions (Just et al., 2007a). These studies demonstrated the proof of principle of this new method in the field of otorhinolaryngology. With the development of rigid endoscopes and coupling onto the confocal microscope, a new application field has opened.

Improvement of the confocal microscope is an ongoing process. Since the first application of this new technology in animal experiments, several improvements to the technique have been accomplished. Among these, manual setting of the starting plane, automatic volume scans and improvement in image quality should be mentioned (Farahati et al., 2010). A further improvement includes on-line mapping during investigation. Image sizes of $400 \mathrm{x}$ $400 \mu \mathrm{m}$ only allow off-line mapping of defined tissue regions. Large-scale maps may help to reduce the time required for re-locating tissue regions previously scanned. This method was first described for on-line mapping of corneal structures (Zhivov et al., 2010; Zhivov et al., 2009). Figure 16 demonstrates an on-line scan of a human tongue base. 
Combination of RCE with other new technologies, for example Optical Coherence Tomography, is another aspect. OCT is a relatively new technology in laryngology. This technique has two major advantages over confocal microscopy. Firstly, OCT allows imaging of tissue layers, including the basal membrane. Optical cross-sections of the tissue (about 2 $\mathrm{mm}$ ) can be displayed. The images can later be compared with the histopathology. Assessment of the integrity of the basal membrane is important for diagnosis of laryngeal lesions. Secondly, new OCT devices are coupled onto an operating microscope (Just et al., 2009). In contrast to previously published data on OCT devices, which mostly required special probes (Armstrong et al., 2006; Wong et al., 2005), OCT with an operating microscope allows a non-contact application. The optical system of the microscope can be used in its complete range without changing the center of field of vision, allowing very precise correlations between the location of the B-scan and the biopsy taken for histopathology (Just et al., 2010). But, cross sections of the tissue may also be a disadvantage of OCT compared to confocal microscopy. The latter method supplies en-face images and displays cellular and sub-cellular information on the tissue.

Intraoperative OCT measurements also allow the use of a rigid endoscope for confocal microscopy. With regard to OCT, RCE and other new technologies, primary research is required to validate the new technologies and to develop their clinical application for early detection of laryngeal cancer and its precursors (Hughes et al., 2010). The method demonstrated here will be explored in a multicenter study in patients with laryngeal cancer and its precursors. A new and non-invasive technology for diagnosis of laryngeal diseases should improve the accuracy of biopsies and reduce non-diagnostic biopsies.

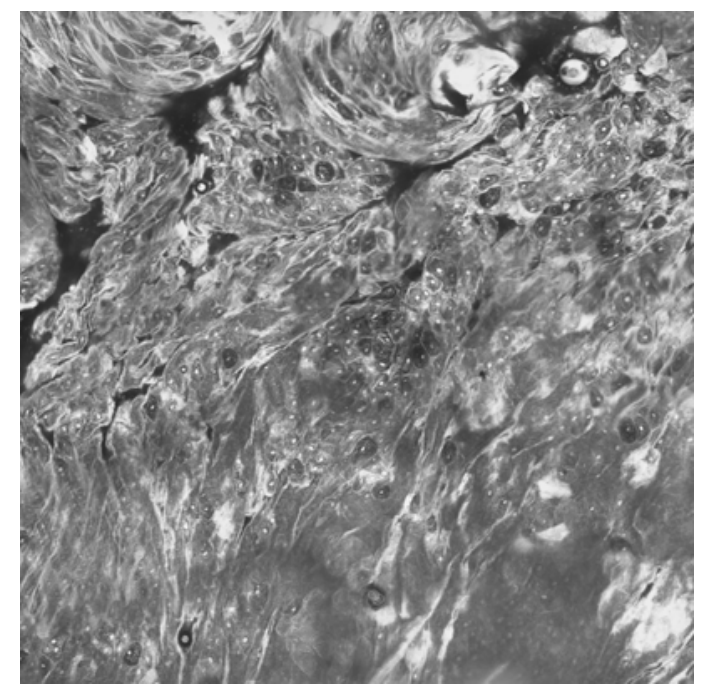

Fig. 16. On-line mapping of the human tongue edge (image size $3.2 \times 3.2 \mathrm{~mm}$ ).

\section{References}

Amos, W.B. \& White, J.G. (2003). How the confocal laser scanning microscope entered biological research. Biol Cell, 95, 6, 335-42 
Andrea, M.; Dias, O. \& Santos, A. (1995a). Contact endoscopy during microlaryngeal surgery: a new technique for endoscopic examination of the larynx. Ann Otol Rhinol Laryngol, 104, 5, 333-9

Andrea, M.; Dias, O. \& Santos, A. (1995b). Contact endoscopy of the vocal cord: normal and pathological patterns. Acta Otolaryngol, 115, 2, 314-6

Arens, C.; Glanz, H.; Dreyer, T. \& Malzahn, K. (2003). Compact endoscopy of the larynx. Ann Otol Rhinol Laryngol, 112, 2, 113-9

Arens, C.; Reussner, D.; Woenkhaus, J.; Leunig, A.; Betz, C.S. \& Glanz, H. (2007). Indirect fluorescence laryngoscopy in the diagnosis of precancerous and cancerous laryngeal lesions. Eur Arch Otorhinolaryngol, 264, 6, 621-6

Armstrong, W.B.; Ridgway, J.M.; Vokes, D.E.; Guo, S.; Perez, J.; Jackson, R.P.; Gu, M.; Su, J.; Crumley, R.L.; Shibuya, T.Y.; Mahmood, U.; Chen, Z. \& Wong, B.J. (2006). Optical coherence tomography of laryngeal cancer. Laryngoscope, 116, 7, 1107-13

Batsakis, J.G. (1999). Surgical excision margins: a pathologist's perspective. Adv Anat Pathol, $6,3,140-8$

Brezinski, M.E.; Tearney, G.J.; Bouma, B.E.; Izatt, J.A.; Hee, M.R.; Swanson, E.A.; Southern, J.F. \& Fujimoto, J.G. (1996). Optical coherence tomography for optical biopsy. Properties and demonstration of vascular pathology. Circulation, 93, 6, 1206-13

Brunsting, A. \& Mullaney, P.F. (1974). Differential light scattering from spherical mammalian cells. Biophys J, 14, 6, 439-53

Carriero, E.; Galli, J.; Fadda, G.; Di Girolamo, S.; Ottaviani, F. \& Paludetti, G. (2000). Preliminary experiences with contact endoscopy of the larynx. Eur Arch Otorhinolaryngol, 257, 2, 68-71

Cikojevic, D.; Gluncic, I. \& Pesutic-Pisac, V. (2008). Comparison of contact endoscopy and frozen section histopathology in the intra-operative diagnosis of laryngeal pathology. J Laryngol Otol, 122, 8, 836-9

Colden, D.; Zeitels, S.M.; Hillman, R.E.; Jarboe, J.; Bunting, G. \& Spanou, K. (2001). Stroboscopic assessment of vocal fold keratosis and glottic cancer. Ann Otol Rhinol Laryngol, 110, 4, 293-8

Collier, T.; Lacy, A.; Richards-Kortum, R.; Malpica, A. \& Follen, M. (2002). Near real-time confocal microscopy of amelanotic tissue: detection of dysplasia in ex vivo cervical tissue. Acad Radiol, 9, 5, 504-12

Csanady, M.; Kiss, J.G.; Ivan, L.; Jori, J. \& Czigner, J. (2004). ALA (5-aminolevulinic acid)induced protoporphyrin IX fluorescence in the endoscopic diagnostic and control of pharyngo-laryngeal cancer. Eur Arch Otorhinolaryngol, 261, 5, 262-6

Delank, W.; Khanavkar, B.; Nakhosteen, J.A. \& Stoll, W. (2000). A pilot study of autofluorescent endoscopy for the in vivo detection of laryngeal cancer. Laryngoscope, 110, $3 \mathrm{Pt}$ 1, 368-73

Farahati, B.; Stachs, O.; Prall, F.; Stave, J.; Guthoff, R.; Pau, H.W. \& Just, T. (2010). Rigid confocal endoscopy for in vivo imaging of experimnetal oral squamous intraepithelial lesions. J Oral Pathol Med, 39, 4, 318-327

Gillenwater, A.; Jacob, R. \& Richards-Kortum, R. (1998). Fluorescence spectroscopy: a technique with potential to improve the early detection of aerodigestive tract neoplasia. Head Neck, 20, 6, 556-62 
Harries, M.L.; Lam, S.; MacAulay, C.; Qu, J. \& Palcic, B. (1995). Diagnostic imaging of the larynx: autofluorescence of laryngeal tumours using the helium-cadmium laser. $J$ Laryngol Otol, 109, 2, 108-10

Haxel, B.R.; Goetz, M.; Kiesslich, R. \& Gosepath, J. (2010). Confocal endomicroscopy: a novel application for imaging of oral and oropharyngeal mucosa in human. Eur Arch Otorhinolaryngol, 267, 3, 443-8

Hughes, O.R.; Stone, N.; Kraft, M.; Arens, C. \& Birchall, M.A. (2010). Optical and molecular techniques to identify tumor margins within the larynx. Head Neck; in press,

Just, T.; Bombor, I.; Pau, H.W.; Klautke, G. \& Fietkau, R. (2006a). Paraneoplastic changes of oropharyngeal mucosa in breast cancer. Strahlenther Onkol, 182, 2, 112-5

Just, T.; Lankenau, E.; Hüttmann, G. \& Pau, H.W. (2009). Intra-operative application of optical coherence tomography with an operating microscope. J Laryngol Otol, 123, 9, 1027-30

Just, T.; Lankenau, E.; Prall, F.; Hüttmann, G.; Pau, H.W. \& Sommer, K. (2010). Optical coherence tomography allows for the reliable identification of laryngeal epithelial dysplasia and for precise biopsy: a clinicopathological study of 61 patients undergoing microlaryngoscopy. Laryngoscope, in press,

Just, T.; Stave, J.; Boltze, C.; Wree, A.; Kramp, B.; Guthoff, R.F. \& Pau, H.W. (2006b). Laser scanning microscopy of the human larynx mucosa: a preliminary, ex vivo study. Laryngoscope, 116, 7, 1136-41

Just, T.; Stave, J.; Bombor, I.; Kreutzer, H.-J.; Guthoff, R. \& Pau, H.W. (2007a). In vivo diagnosis of epithelial changes of the oropharynx using confocal microscopy. Laryngorhinootologie, 87, 3, 174-80 (in German)

Just, T.; Stave, J.; Bombor, I.; Kreutzer, H.J.; Guthoff, R. \& Pau, H.W. (2008). In vivo diagnosis of epithelial changes of the oropharynx using confocal microscopy. Laryngorhinootologie, 87, 3, 174-80 (in German)

Just, T.; Stave, J.; Kreutzer, H.J.; Guthoff, R. \& Pau, H.W. (2007b). Confocal microscopic evaluation of epithelia of the larynx. Laryngorhinootologie, 86, 9, 644-8 (in German)

Just, T.; Stave, J.; Pau, H.W. \& Guthoff, R. (2005). In-vivo observation of papillae of the human tongue using confocal laser scanning microscopy. ORL J Otorhinolaryngol Relat Spec, 67, 4, 207-212

Kawaida, M.; Fukuda, H. \& Kohno, N. (1998). Multidirectional observations of the larynx using transurethral rigid endoscopes during direct laryngoscopy. J Laryngol Otol, $112,5,464-6$

Kiesslich, R.; Burg, J.; Vieth, M.; Gnaendiger, J.; Enders, M.; Delaney, P.; Polglase, A.; McLaren, W.; Janell, D.; Thomas, S.; Nafe, B.; Galle, P.R. \& Neurath, M.F. (2004). Confocal laser endoscopy for diagnosing intraepithelial neoplasias and colorectal cancer in vivo. Gastroenterology, 127, 3, 706-13

Kiesslich, R.; Goetz, M.; Vieth, M.; Galle, P.R. \& Neurath, M.F. (2005). Confocal laser endomicroscopy. Gastrointest Endosc Clin N Am, 15, 4, 715-31

Kiesslich, R.; Hoffman, A. \& Neurath, M.F. (2006). Colonoscopy, tumors, and inflammatory bowel disease - new diagnostic methods. Endoscopy, 38, 1, 5-10

Kiesslich, R. \& Neurath, M.F. (2005). Endoscopic detection of early lower gastrointestinal cancer. Best Pract Res Clin Gastroenterol, 19, 6, 941-61

Kiesslich, R. \& Neurath, M.F. (2006). Magnifying chromoendoscopy for the detection of premalignant gastrointestinal lesions. Best Pract Res Clin Gastroenterol, 20, 1, 59-78 
Kleinsasser, O. (1962). Die Laryngomikroskopie (Lupenlaryngoskopie) und ihre Bedeutung für die Erkennung der Vorerkrankungen und Frühformen des Stimmlippenkarzinoms. Arch Ohren Nasen Kehlkopfheilkd, 180, 724-7

Kothe, C.; Münzenmayer, C.; Wittenberg, T. \& Hess, M. (2005). Erfahrungen mit optischen Stimmlippenbiopsien bei Leukoplakien. Laryngorhinootologie, 84, 2, 92-5

Lüerßen, K.; Lubatschowski, H.; Ursinus, K.; Gasse, H.; Koch, R. \& Ptok, M. (2006). Charakterisierung von Stimmlippen mittels optischer Kohärenztomographie. HNO, $54,8,611-615$

Malzahn, K.; Dreyer, T.; Glanz, H. \& Arens, C. (2002). Autofluorescence endoscopy in the diagnosis of early laryngeal cancer and its precursor lesions. Laryngoscope, 112, 3, 488-93

McGuirt, W.F. \& Browne, J.D. (1991). Management decisions in laryngeal carcinoma in situ. Laryngoscope, 101, 2, 125-9

Rajadhyaksha, M.; Grossman, M.; Esterowitz, D.; Webb, R.H. \& Anderson, R.R. (1995). In vivo confocal scanning laser microscopy of human skin: melanin provides strong contrast. J Invest Dermatol, 104, 6, 946-52

Schmitt, J.M. (1999). Optican coherance tomography (OCT): a review. IEEE J Sel Top Quan, 5, $1205-1215$

Schmitt, J.M.; Lee, S.L. \& Yung, K.M. (1997). An optical coherence microscope with enhanced resolving power in thick tissue. Opt Common, 142, 203-207

Stave, J.; Zinser, G.; Grummer, G. \& Guthoff, R. (2002). Modified Heidelberg Retinal Tomograph HRT. Initial results of in vivo presentation of corneal structures. Ophthalmologe, 99, 4, 276-80 (in German)

Venkatesh, K.; Cohen, M.; Evans, C.; Delaney, P.; Thomas, S.; Taylor, C.; Abou-Taleb, A.; Kiesslich, R. \& Thomson, M. (2009). Feasibility of confocal endomicroscopy in the diagnosis of pediatric gastrointestinal disorders. World J Gastroenterol, 15, 18, 2214-9

Wardrop, P.J.; Sim, S. \& McLaren, K. (2000). Contact endoscopy of the larynx: a quantitative study. J Laryngol Otol, 114, 6, 437-40

White, W.M.; Rajadhyaksha, M.; Gonzalez, S.; Fabian, R.L. \& Anderson, R.R. (1999). Noninvasive imaging of human oral mucosa in vivo by confocal reflectance microscopy. Laryngoscope, 109, 10, 1709-17

Wong, B.J.; Jackson, R.P.; Guo, S.; Ridgway, J.M.; Mahmood, U.; Su, J.; Shibuya, T.Y.; Crumley, R.L.; Gu, M.; Armstrong, W.B. \& Chen, Z. (2005). In vivo optical coherence tomography of the human larynx: normative and benign pathology in 82 patients. Laryngoscope, 115, 11, 1904-11

Zhivov, A.; Blum, M.; Guthoff, R. \& Stachs, O. (2010). Real-time mapping of the subepithelial nerve plexus by in vivo confocal laser scanning microscopy. $\mathrm{Br} \mathrm{J}$ Ophthalmol, 94, 9, 1133-5

Zhivov, A.; Guthoff, R. \& Stachs, O. (2009). On-line mapping of corneal structures with in vivo laser scanning microscopy. Klin Monbl Augenheilkd, 226, 12, 980-3 (in German) 


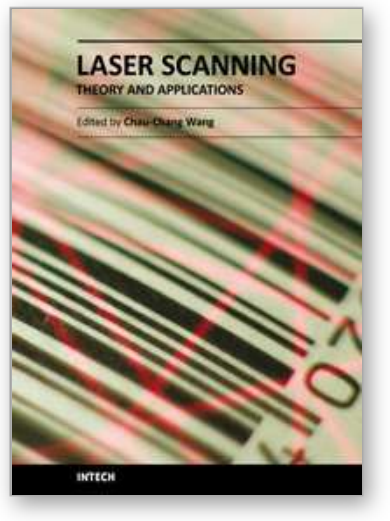

\author{
Laser Scanning, Theory and Applications \\ Edited by Prof. Chau-Chang Wang
}

ISBN 978-953-307-205-0

Hard cover, 566 pages

Publisher InTech

Published online 26, April, 2011

Published in print edition April, 2011

Ever since the invention of laser by Schawlow and Townes in 1958, various innovative ideas of laser-based applications emerge very year. At the same time, scientists and engineers keep on improving laser's power density, size, and cost which patch up the gap between theories and implementations. More importantly, our everyday life is changed and influenced by lasers even though we may not be fully aware of its existence. For example, it is there in cross-continent phone calls, price tag scanning in supermarkets, pointers in the classrooms, printers in the offices, accurate metal cutting in machine shops, etc. In this volume, we focus the recent developments related to laser scanning, a very powerful technique used in features detection and measurement. We invited researchers who do fundamental works in laser scanning theories or apply the principles of laser scanning to tackle problems encountered in medicine, geodesic survey, biology and archaeology. Twenty-eight chapters contributed by authors around the world to constitute this comprehensive book.

\title{
How to reference
}

In order to correctly reference this scholarly work, feel free to copy and paste the following:

Tino Just, Joachim Stave, Oliver Stachs, Gabriele Witt, Rudolf Guthoff and Hans Wilhelm Pau (2011). Rigid Confocal Endoscopy of the Larynx, Laser Scanning, Theory and Applications, Prof. Chau-Chang Wang (Ed.), ISBN: 978-953-307-205-0, InTech, Available from: http://www.intechopen.com/books/laser-scanning-theoryand-applications/rigid-confocal-endoscopy-of-the-larynx

\section{INTECH}

open science | open minds

\section{InTech Europe}

University Campus STeP Ri

Slavka Krautzeka 83/A

51000 Rijeka, Croatia

Phone: +385 (51) 770447

Fax: +385 (51) 686166

www.intechopen.com

\section{InTech China}

Unit 405, Office Block, Hotel Equatorial Shanghai

No.65, Yan An Road (West), Shanghai, 200040, China

中国上海市延安西路65号上海国际贵都大饭店办公楼405单元

Phone: +86-21-62489820

Fax: $+86-21-62489821$ 
(C) 2011 The Author(s). Licensee IntechOpen. This chapter is distributed under the terms of the Creative Commons Attribution-NonCommercialShareAlike-3.0 License, which permits use, distribution and reproduction for non-commercial purposes, provided the original is properly cited and derivative works building on this content are distributed under the same license. 